\title{
CLINICAL BACKGROUND OF RHEUMATOID VASCULAR DISEASE
}

\author{
BY \\ M. WILKINSON AND W. N. TORRANCE \\ From the Rheumatic Unit, Bridge of Earn Hospital, Perthshire
}

During the past 15 years awareness of vascular lesions complicating rheumatoid arthritis has increased and such lesions are now commonly recognized both during. life and at autopsy. Scott, Hourihane, Doyle, Steiner, Laws, Dixon, and Bywaters (1961) have classified rheumatoid vascular lesions into three main pathological groups:

(1) Digital arterial narrowing with intimal proliferation but usually without necrotic or granulomatous lesions;

(2) Sub-acute lesions in small blood vessels within muscles;

(3) Severe wide-spread necrotizing arteritis indistinguishable from poly-arteritis nodosa.

Whether or not these are simply different stages of the same disease process is unknown, but certainly rheumatoid subjects not uncommonly show more than one type of lesion during the later stages of the disease.

The most readily recognized clinical manifestations of rheumatoid vascular disease are those involving the skin. Crops of nail-edge lesions and petechia-like lesions of the finger pulps and bony prominences are not uncommon if sought repeatedly and diligently (Golding, Hamilton, and Gill, 1965). Less common are Raynaud's phenomenon, cutaneous nodules over bony prominences, chronic leg ulcers, erythematous macular and papular rashes, and livedo reticularis. Peripheral neuropathy from involvement of vasa nervorum may occur with or without skin lesions, but other features such as episcleritis, renal hypertension, and gangrene usually imply a more widespread necrotizing arteritis with a much poorer prognosis.

In this study a group of 260 hospital patients with rheumatoid arthritis have been analysed according to the presence or absence of vascular lesions in the hope of uncovering those features associated with, and perhaps predisposing to, vasculitis.

\section{Material and Methods}

Case notes of patients seen repeatedly during the 2-year period ending July, 1966, were reviewed, and only those containing all required information were included in the study. Since in-patient records were usually more complete, the cases included contained an excess of patients with disease of sufficient severity or chronicity to require admission to hospital.

The information sought included a full history with details of past treatment. Any patient receiving corticosteroids for 3 months or more was accepted into the corticosteroid-treated category. The family history included positive information about all first-degree relatives and the results of inquiry for more distant relatives with rheumatoid arthritis and other related and possible auto-immune diseases, including psoriasis, ulcerative colitis, diabetes mellitus, pernicious anaemia, thyroid disease, and asthma. Positive responses were checked by interrogation of the patient and only a clear description of a disease in a relative was accepted. Only occasionally were affected relatives contacted. All patients were examined repeatedly for extra-articular lesions and for possible vascular lesions. Only those with cutaneous vascular lesions or with histologicallyproved rheumatoid vascular disease were included in the arteritic group. The occurrence of myocardial and cerebral infarction was not allowed to support the diagnosis of rheumatoid arteritis, since so many patients belonged to an age group where such lesions might be expected on an atherosclerotic basis. Tests for rheumatoid factor, using either sheep cells or latex particles, were performed only once if positive but were repeated at least once during the study if negative. All patients fulfilled the clinical criteria for "definite" or "classical" rheumatoid arthritis laid down by the American Rheumatism Association (Ropes, Bennett, Cobb, Jacox, and Jessar, 1959), but three patients included in the rheumatoid arteritic group would have been excluded from the American Rheumatısm Association classification because they showed histological evidence of polyarteritis. The patients were grouped according to the presence or absence of vascular lesions. None of those with vascular disease had active psoriasis although one gave a history 
of previous skin lesions, and all gave positive tests for rheumatoid factor. The remaining patients without recognized vascular disease were subdivided according to the presence or absence of rheumatoid factor and, because of the uncertain relationship between psoriasis and rheumatoid arthritis, twenty patients with psoriasis (seven sero-positive, thirteen sero-negative) were grouped separately. Statistical comparisons were made between the arteritic group and each of the other three groups of patients, using the $\chi^{2}$ test with Yates's modification where appropriate.

\section{Results}

Details of the various groups of patients are shown in Table I.

Most alike were the arteritic and sero-positive non-arteritic groups, yet even here significant differences emerged; in patients with vascular disease there was a longer average duration of disease and a greater incidence of subcutaneous nodules. The differences in duration of disease and in the incidence of subcutaneous nodules were even greater between the arteritic group and the sero-negative patients but in addition the latter group included significantly fewer patients treated with corticosteroids and more patients with less than four joints affected. The psoriatic group was distinguished from the arteritic patients by a shorter duration of disease and by the infrequency of both subcutaneous nodules and positive serological tests.

Table II shows the incidence of other diseases included in the inquiry among the patients and their first-degree relatives. While the incidence of rheumatoid arthritis among relatives of arteritic patients was not greatly different from that of relatives of sero-positive non-arteritic patients, it was significantly higher than among relatives of sero-negative and psoriatic patients. Unexpectedly, the incidence of psoriasis was higher among relatives of arteritic patients than among relatives of seropositive and sero-negative non-arteritic patients.

TABLE I

CLINICAL DETAILS OF PATIENTS STUDIED

\begin{tabular}{|c|c|c|c|c|c|c|c|c|c|c|}
\hline \multirow{2}{*}{ Arteritis } & \multirow[b]{2}{*}{$\cdots$} & \multirow[b]{2}{*}{$\cdots$} & \multirow[b]{2}{*}{$\cdots$} & \multirow[b]{2}{*}{$\cdots$} & \multirow[b]{2}{*}{$\cdots$} & \multirow[b]{2}{*}{$\cdots$} & \multirow{2}{*}{ Present } & \multicolumn{3}{|c|}{ Absent } \\
\hline & & & & & & & & Sero-positive & Sero-negative & Psoriasis \\
\hline \multicolumn{2}{|c|}{$\begin{array}{l}\text { No. of Patients } \\
\text { No. Sero-positive } \\
\text { Percentage of Males }\end{array}$} & $\begin{array}{l}\cdots \\
\cdots \\
\cdots\end{array}$ & $\begin{array}{l}\cdots \\
\cdots \\
\cdots\end{array}$ & $\begin{array}{l}\cdots \\
\cdots \\
\cdots\end{array}$ & $\begin{array}{l}\cdots \\
\cdots \\
\cdots\end{array}$ & $\begin{array}{l}\cdots \\
\cdots \\
\cdots\end{array}$ & $\begin{array}{l}40 \\
40 \\
32 \cdot 5\end{array}$ & $\begin{array}{r}131 \\
131 \\
29 \cdot 8\end{array}$ & $\begin{array}{c}69 \\
0 \\
21 \cdot 7\end{array}$ & $\begin{array}{r}20 \\
7 \\
25\end{array}$ \\
\hline Mean Age (yrs) & \multicolumn{4}{|c|}{$\begin{array}{l}\text { At onset of disease } \\
\text { At midpoint of study }\end{array}$} & $\cdots$ & $\begin{array}{l}\cdots \\
\cdots\end{array}$ & $\begin{array}{l}43 \cdot 2 \\
56 \cdot 8\end{array}$ & $\begin{array}{l}44 \cdot 7 \\
55\end{array}$ & $\begin{array}{l}44 \cdot 8 \\
53 \cdot 1 *\end{array}$ & $\begin{array}{l}47 \cdot 1 \\
57 \cdot 1\end{array}$ \\
\hline \multicolumn{4}{|c|}{ Mean Duration of Disease (yrs) } & $\cdots$ & . & $\cdots$ & $13 \cdot 3$ & $10 \cdot 4^{* * *}$ & $8 \cdot 3 * * *$ & $10^{*}$ \\
\hline \multicolumn{6}{|c|}{ Previous Steroid Therapy (per cent. of patients) } & . & $67 \cdot 5$ & $58 \cdot 8$ & $36 \cdot 2^{*}$ & 60 \\
\hline \multicolumn{7}{|c|}{ Percentage of Patients with Less than 4 Joints } & 0 & $4 \cdot 6$ & $21 \cdot 8 * *$ & 10 \\
\hline \multicolumn{7}{|c|}{ Percentage of Patients with Subcutaneous Nodules } & $67 \cdot 5$ & $25 \cdot 2^{* * *}$ & $0 * * *$ & $5 * * *$ \\
\hline \multicolumn{5}{|c|}{ No. of Deaths up to 6 months after Study } & $\cdots$ & . & 11 & $1 * * *$ & $1 * * *$ & $0^{* * *}$ \\
\hline
\end{tabular}

The patients with arteritis have been compared with each of three groups of patients without arteritis and significant differences are expressed as follows:

$$
*=\mathrm{P}<0.05 \quad * *=\mathrm{P}<0.01 \quad * * *=\mathrm{P}<0.001
$$

TABLE II

INCIDENCE OF OTHER DISEASES SOUGHT AMONG RHEUMATOID SUBJECTS AND THEIR FIRST DEGREE RELATIVES.

\begin{tabular}{|c|c|c|c|c|c|c|c|c|c|c|c|c|c|}
\hline \multirow{3}{*}{$\begin{array}{l}\text { Arteritis } \\
\text { Series } \\
\end{array}$} & \multirow{3}{*}{$\begin{array}{l}\cdots \\
\cdots\end{array}$} & \multirow{3}{*}{$\cdots$} & \multirow{3}{*}{$\cdots$} & \multirow{3}{*}{$\cdots$} & \multirow{3}{*}{$\begin{array}{l}\cdots \\
\cdots\end{array}$} & \multirow{2}{*}{\multicolumn{2}{|c|}{ Present }} & \multicolumn{6}{|c|}{ Absent } \\
\hline & & & & & & & & \multicolumn{2}{|c|}{ Sero-positive } & \multicolumn{2}{|c|}{ Sero-negative } & \multicolumn{2}{|c|}{ Psoriasis } \\
\hline & & & & & & Patients & Relatives & Patients & Relatives & Patients & Relatives & Patients & Relatives \\
\hline Total .. & $\cdots$ & $\cdots$ & $\cdots$ & $\cdots$ & $\cdots$ & 40 & 324 & 131 & 1,093 & 69 & 531 & 20 & 161 \\
\hline \multicolumn{4}{|c|}{$\begin{array}{l}\text { No. with rheumatoid arthritis } \\
\text { No. with psoriasis . . } \\
\text { No. with ulcerative colitis } . . \\
\text { No. with diabetes mellitus } \\
\text { No. with pernicious anaemia } \\
\text { No. with thyroid disease } \quad . \\
\text { No. with asthma } \quad .\end{array}$} & $\begin{array}{l}\cdots \\
\cdots \\
\cdots \\
\cdots \\
\cdots\end{array}$ & $\begin{array}{l}\cdots \\
\cdots \\
\cdots \\
\cdots \\
\cdots \\
\cdots\end{array}$ & $\begin{array}{r}40 \\
1 \\
0 \\
0 \\
0 \\
3 \\
1\end{array}$ & $\begin{array}{r}16 \\
7 \\
0 \\
3 \\
0 \\
2 \\
5\end{array}$ & $\begin{array}{r}131 \\
0 \\
0 \\
4 \\
0 \\
10 \\
3\end{array}$ & $\begin{array}{r}41 \\
5^{* * *} \\
1 \\
13 \\
1 \\
10 \\
15\end{array}$ & $\begin{array}{r}69 \\
0 \\
0 \\
5 \\
0 \\
1 \\
3\end{array}$ & $\begin{array}{c}11^{*} \\
3^{*} \\
0 \\
7 \\
4 \\
3 \\
3\end{array}$ & $\begin{array}{r}21 \\
20 \\
0 \\
1 \\
1 \\
1 \\
0\end{array}$ & $\begin{array}{l}7 \\
6 \\
1 \\
6 \\
2 \\
1 \\
3\end{array}$ \\
\hline
\end{tabular}

The arteritic group has been compared with each of the three groups of patients without arteritis and significant differences are indicated as in Table $I$. 
Extra-articular manifestations of rheumatoid disease were recognized infrequently but there was no evidence that these lesions were unduly common in any one group of patients (see Table III).

Of interest is the very much higher mortality observed in the arteritic patients during the period of study and the succeeding 6 months. The mortality figures have been included in Table I.

\section{Discussion}

No hospital study, especially one weighted by the inclusion of seriously-ill rheumatoid patients, can give an accurate estimate of the frequency of rheumatoid vascular disease. Nevertheless, comparisons between patients with and without vascular complications should provide an indication of the type of patient most liable to these prognostically unfavourable complications and perhaps give a clue to their significance. Such comparisons must be made with the appreciation that the various groups are difficult to define accurately owing to the intermittent character of vascular lesions, and classification at a later date would, no doubt, differ because of the later appearance of vascular lesions, psoriasis, or positive tests for rheumatoid factor.

The present analysis confirms previous studies (Bywaters and Scott, 1963; Epstein and Engleman, 1959; Golding and others, 1965; Schmid, Cooper, Ziff, and McEwen, 1961) in respect of the almost invariable demonstration of rheumatoid factor and the frequent occurrence of subcutaneous nodules in patients with rheumatoid vascular disease. However, in two respects this study differs. Most writers emphasize the frequency of vascular disease in male rheumatoid subjects but only Golding and others (1965) actually compared the sex incidence in cases with and without vascular lesions. Though they commented on the excess of male patients with vascular disease, this excess was not statistically significant. Secondly, most writers consider that vascular disease is unduly frequent in patients treated with corticosteroids (Johnson, Smyth, Holt, Lubchenco, and Valentine, 1959; Kemper, Baggenstoss, and Slocumb, 1957; Sokoloff and Bunim, 1957). Bywaters and Scott (1963) doubted the significance of corticosteroid therapy and point out that seriously-ill patients such as are liable to vascular complications are prone to be treated with corticosteroids. In this study rather more patients with vascular disease than patients in the seropositive non-arteritic group had received corticosteroids, but the difference was not statistically significant. Unfortunately, it proved impossible to compare the actual dosage of corticosteroids because of the fluctuation in dosage and the doubtful validity of the doses recorded during out-patient supervision. The absence of clinically-observed vascular lesions in patients treated for long periods with corticosteroid drugs for other diseases such as ulcerative colitis makes it rather unlikely that these drugs can do more than trigger off an occult tendency to rheumatoid vascular disease, and even this seems doubtful from our experience.

In most respects the patients with vascular disease resembled the sero-positive patients without vascular lesions, and the significant differences found (i.e. in duration of disease and incidence of subcutaneous nodules) were differences of degree only. Possibly another difference, not tested in this study, might be found in the serum titres of rheumatoid factor, for Epstein and Engleman (1959) noted particularly high titres in patients with vascular complications, but none of these would contradict the thesis that rheumatoid vascular disease is merely a late manifestation of severe and prolonged sero-positive rheumatoid disease. The absence of clinicallyobserved vascular complications and the rarity of subcutaneous nodules in sero-negative and psoriatic patients only serve to emphasize the association of arteritis, subcutaneous nodules, and rheumatoid factor.

From histological evidence it has been suggested

TABLE III

EXTRA-ARTICULAR LESIONS NOT ATTRIBUTABLE TO VASCULAR DISEASE FOUND IN PATIENTS STUDIED

\begin{tabular}{|c|c|c|c|c|c|c|c|c|c|c|c|}
\hline \multirow{2}{*}{ Arteritis } & \multirow{2}{*}{. } & \multirow{2}{*}{$\cdots$} & \multirow{2}{*}{$\cdots$} & \multirow{2}{*}{$\cdots$} & \multirow{2}{*}{. } & \multirow{2}{*}{. } & \multirow{2}{*}{$\cdots$} & \multirow{2}{*}{ Present } & \multicolumn{3}{|c|}{ Absent } \\
\hline & & & & & & & & & Sero-positive & Sero-negative & Psoriasis \\
\hline Total & . & . & . & . & $\cdots$ & $\cdots$ & $\cdots$ & 40 & 131 & 69 & 20 \\
\hline \multicolumn{4}{|c|}{$\begin{array}{l}\text { No. with Sjøgren's disease } \\
\text { No. with Lymphadenopathy } \\
\text { No. with Splenomegaly. } \\
\text { No. with Pleurisy with effusion } \\
\text { No. with Pericarditis } \quad . \\
\text { No. with Renal failure } \quad . \\
\text { No. with Hypertension } \quad \text {.. }\end{array}$} & $\begin{array}{l}\cdots \\
\cdots \\
\cdots \\
\cdots \\
\cdots\end{array}$ & $\begin{array}{l}\cdots \\
\cdots \\
\cdots \\
\cdots \\
\cdots\end{array}$ & $\begin{array}{l}\cdots \\
\cdots \\
\cdots \\
\cdots \\
\cdots\end{array}$ & $\begin{array}{l}. \\
\therefore \\
\because \\
\because \\
\because \\
\therefore\end{array}$ & $\begin{array}{r}0 \\
2 \\
3 \\
0 \\
2 \\
4 \\
11\end{array}$ & $\begin{array}{r}5 \\
3 \\
7 \\
3 \\
0 \\
2 \\
26\end{array}$ & $\begin{array}{r}0 \\
2 \\
0 \\
1 \\
0 \\
2 \\
22\end{array}$ & $\begin{array}{l}0 \\
1 \\
0 \\
0 \\
0 \\
0 \\
4\end{array}$ \\
\hline
\end{tabular}


that the subcutaneous nodules begin as a focal arteritis or venulitis - that they are, in fact, an early manifestation of vascular disease (Sokoloff, McCluskey, and Bunim, 1953; Kulka, 1959). The fact that subcutaneous nodules may precede other features of vascular disease by many years need not contradict this suggestion for, as Bywaters and Scott (1963) were the first to point out, nail-edge lesions of rheumatoid vascular disease may similarly precede more florid and dangerous vascular lesions by some years. Because of the strong association it seems likely that rheumatoid factor is somehow involved in the pathogenesis of rheumatoid vascular disease, and Epstein and Engleman (1959) have even suggested that the vascular lesions result from precipitations of rheumatoid factor in the vessel wall. Such localization of rheumatoid factor has been demonstrated in mild degree by immunofluorescent methods (Kaplan and Vaughan, 1959), though whether such precipitation causes tissue damage is unknown.

Another aspect is the relationship of clinical vascular lesions to duration of disease in sero-positive patients. It is of interest that, from comparatively early in the disease, abnormalities in the minute synovial vessels are readily observed. These include cellular intimal thickening, sometimes leading to occlusion of arterioles and venules with occasional infarction. Necrosis of vessel walls is much less common. While such changes may be seen near any chronic inflammatory focus, it is curious that with the passage of time so many rheumatoid patients develop intimal thickening of digital arterioles, sparse granulomatous and necrotic lesions in small arteries and arterioles supplying muscles, and eventually, in a minority, a patchy polyarteritis nodosa-like picture which now extends to larger arteries. One's impression is of vasculitis slowly extending in distribution and increasing in severity.

At the beginning of this investigation it was suspected that the patients with vascular lesions would prove to be those with severe disease possibly dictated by a particularly prominent genetic factor. This does not appear to be so, for the incidence of rheumatoid disease among relatives was no different in the arteritic and sero-positive non-arteritic groups. As might be expected from other studies (Bland and Brown, 1964), the incidence amongst relatives of sero-negative patients was significantly lower. The incidence of psoriasis among the relatives of patients with vascular disease seems strangely high, but possibly this is highlighted by our comparing them with relatives of patients without vascular disease, from which we have extracted patients with psoriasis and grouped them separately.

Nor can we confirm the impression of Golding and others (1965) that extra-articular rheumatoid lesions such as pleurisy and pericarditis are especially common in histories of patients with vascular disease. Unfortunately, such extra-articular manifestations were recognized so infrequently that comparisons between groups were valueless.

The pattern of disease during the period of followup of these cases emphasizes two points. Firstly, while some patients with only nail-edge lesions, especially when these are minute and infrequent, may survive for long periods, as Bywaters and Scott (1963) have emphasized, the mortality amongst this group of patients is far higher than amongst patients without vascular lesions. Secondly, some patients show a tendency to develop nail-edge lesions of increasing size and frequency until occlusion of a moderate-sized artery results in gangrene or visceral infarction. In some patients, vascular lesions on the fingers and ischaemic leg ulcers may be precipitated by trauma or by exposure to cold, but eventually long-surviving patients may develop showers of arteritic lesions even when bedridden. There seems to be a continuous spectrum ranging from sero-positive rheumatoid disease without clinically apparent vascular disease, through minor vascular lesions which possibly include subcutaneous nodules and nail-edge lesions, to frank polyarteritis of small and medium-sized vessels. The movement of patients across this spectrum seems to relate largely to duration and severity of disease and this suggests that the arteritis is an integral and common feature of sero-positive rheumatoid disease and not a rare complication affecting some special group of patients.

\section{Summary}

Cases of rheumatoid arthritis with and without vascular complications have been compared. The patients with vascular lesions were all sero-positive, but showed a significantly longer duration of disease, a higher incidence of subcutaneous nodules, a similar incidence of previous corticosteroid therapy, and a much poorer prognosis when compared with sero-positive patients without clinical vascular disease. The differences in duration of disease and incidence of subcutaneous nodules were even more marked between the patients with vascular lesions and the sero-negative patients, but in addition the latter included significantly more with less than four joints affected and fewer previously treated with corticosteroids.

Detailed family histories revealed a similar 
incidence of rheumatoid arthritis among the relatives of sero-positive patients with and without vascular lesions, but significantly fewer cases among the relatives of sero-negative patients. Of the other diseases sought, the only significant finding was a higher incidence of psoriasis among relatives of patients with vascular disease.
It is suggested that rheumatoid vascular disease represents an extension in severity and distribution of microscopic vascular changes seen early in seropositive rheumatoid disease but that it produces clinically recognizable lesions only at a late stage of the disease.

\section{REFERENCES}

Bland, J. H., and Brown, E. W. (1964). Ann. intern. med., 60, 88 (Sero-negative and sero-positive rheumatoid arthritis: clinical, radiological, and biochemical differences).

Bywaters, E. G. L., and Scott, J. T. (1963). J. chron. Dis., 16, 905 (Natural history of vascular lesions in rheumatoid arthritis).

Epstein, W. V., and Engleman, E. P. (1959). Arthr. and Rheum., 2, 250 (Relation of the rheumatoid factor content of serum to clinical neurovascular manifestations of rheumatoid arthritis).

Golding, J. R., Hamilton, M. G., and Gill, R. S. (1965). Brit. J. Derm., 77, 207 (Arteritis of rheumatoid arthritis).

Johnson, R. L., Smyth, C. J., Holt, G. W., Lubchenco, A., and Valentine, E. (1959). Arthr. and Rheum., 2, 224 (Steroid therapy and vascular lesions in rheumatoid arthritis).

Kaplan, M. H., and Vaughan, J. H. (1959). Ibid., 2, 356 (Reaction of rheumatoid sera with synovial tissue as revealed by fluorescent antibody studies).

Kemper, J. W., Baggenstoss, A. H., and Slocumb, C. H. (1957). Ann. intern. Med., 46, 831 (The relationship of therapy with cortisone to the incidence of vascular lesions in rheumatoid arthritis).

Kulka, J. P. (1959). Bull. rheum. Dis., 10, 201 (The vascular lesions associated with rheumatoid arthritis)

Ropes, M. W., Bennett, G. A., Cobb, S., Jacox, R., and Jessar, R. A. (1959). Ann. rheum. Dis., 18, 49 (1959 Revision of diagnostic criteria for rheumatoid arthritis).

Schmid, F. R., Cooper, N. S., Ziff, M., and McEwen, C. (1961). Amer. J. Med., 30, 56 (Arteritis in rheumatoid arthritis).

Scott, J. T., Hourihane, D. O., Doyle, F. H., Steiner, R. E., Laws, J. W., Dixon, A. St. J. and, Bywaters, E. G. L. (1961). Ann. rheum. Dis., 20, 224 (Digital arteritis in rheumatoid disease).

Sokoloff, L., McCluskey, R. T. and Bunim, J. J. (1953). Arch. Path., 55, 475 (Vascularity of the early subcutaneous nodule of rheumatoid arthritis).

Sokoloff, L., and Bunim, J. J. (1957). J. chron. Dis., 5, 668 (Vascular lesions in rheumatoid arthritis).

\section{Base clinique de la maladie vasculaire rhumatoìde}

\section{RÉSUMÉ}

On a comparé les cas d'arthrite rhumatismale avec et sans complication vasculaire. Les malades ayant des lésions vasculaires avaient tous une sérologie rhumatoïde positive, mais accusaient une évolution significativement plus longue de la maladie, une plus grande fréquence de nodules souscutanés, une incidence analogue de thérapeutique corticostéroïdienne et un pronostic beaucoup plus mauvais que les malades ayant eux aussi une sérologie positive mais sans atteinte vasculaire clinique. Les différences de durée d'évolution de la maladie et de la fréquence de nodules souscutanés étaient même plus nettes lorsqu'il s'agissait de malades ayant des lésions vasculaires et les malades séronégatifs; de plus, parmi ces derniers l'atteinte portait souvent sur moins de quatre articulations et peu d'entre eux avaient reçu des corticostéroides.

L'étude détaillée des familles a montré une fréquence analogue d'arthrite rhumatismale dans la parenté des malades ayant une sérologie positive avec ou sans lésion vasculaire, mais significativement très peu de cas dans la parenté des malades ayant une sérologie négative. Parmi

\section{La base clínica de la enfermedad vascular reumatoide}

\section{SUMARIO}

Se compararon casos de artritis reumatoide con y sin complicación vascular. Todos los enfermos con lesiones vasculares tuvieron una serología reumatoide seropositiva, pero la duración de su enfermedad fué significativamente mayor, los nódules subcutáneos se vieron con más frecuencia, la incidencia de terapia corticosteroide fué similar y el pronóstico mucho peor que él de otros enfermos, también seropositivos, pero sin lesión vascular clínicamente demostrada. Las diferencias respecto a la duración de la enfermedad y la incidencia de los nódulos subcutáneos fueron aún más destacadas entre los enfermos con lesiones vasculares y los enfermos seronegativos; además, en los seronegativos a menudo hubo menos de cuatro articulaciones afectadas y pocos de ellos habían recibido terapia corticosteroide.

Un estudio detallado de las famillas reveló una incidencia similar de artritis reumatoide en los parientes de los pacientes seropositivos con y sin lesión vascular, pero hubo significativamente menos casos en los parientes de los pacientes seronegativos. Respecto a otras enfermedades investigadas, se encontró sólo una mayor incidencia 
les autres maladies étudiées, seule a été significative la découverte d'une plus grande incidence de psoriasis dans la parenté des malades ayant une atteinte vasculaire.

Ceci indique que l'atteinte vasculaire rhumatismale traduit une sévérité et une distribution plus accentuées des altérations vasculaires microscopiques vues précocement dans la maladie rhumatismale séropositive, bien que les lésions cliniquement reconnaissables ne se manifestent qu'à un stade ultérieur de la maladie. de psoriasis en parientes de enfermos con lesiones vasculares.

Se cree que la lesión reumatoide vascular indica una gravedad y una distribución más acentuadas de las alteraciones vasculares microscópicas observadas temprano en la enfermedad reumatoide seropositiva y que estas alteraciones se expresan clìnicamente durante un perìodo más adelantado de la evolución morbosa. 